\title{
PENGARUH KOMPENSASI TERHADAP SEMANGAT KERJA KARYAWAN TETAP PADA PT. PERKEBUNAN NUSANTARA XIV (PERSERO) POLA KERJA SAMA LUWU
}

\author{
NURJANNAH, LANTENG BUSTAMI, SAHARUDDIN
}

\begin{abstract}
ABSTRAK
Pemberian kompensasi adalah suatu cara yang dilakukan perusahaan agar karyawan mempunyai tanggung jawab terhadapperusahaannya. Penelitian ini bertujuan untuk mengetahui tingkat pengaruh kompensasi dengan semangat kerja karyawan pada PTP Nusantara XIV (Persero) PKS Luwu Unit.

Metode penelitian yang digunakan yaitu metode penelitian survey, Penelitian ini dilakukan dengan mengambil sampel dari PTP Nusantara XIV (Persero) Unit Usaha Burau Luwu Utara, dengan jumlah sampel sebanyak 30 responden, dari jumlah populasi seluruh karyawan tetap bukan staff dibagian administrasi.

Berdasarkan hasil penelitian, ditemukan bahwa hasil perhitungan kolerasi rank soearma dengan taraf signifikansi 5\% didapatkan hasil sebesar 0,608 maka dapat disimpulkan bahwa ada pengaruh kuat antara kompensasi terhadap semangat kerja karyawan tetap bagian administrasi, dimana hasil uji signifikan diperoleh nilai tanggapan hitung sebesar 4,09, hasil ini sejalan dengan uji t dimana tabel untuk $d f=$ $\mathrm{N}-2$ = 28 dengan tingkat signifikan 5\%.

Kesimpulnnya bahwa kompensasi berpengaruh terhadap semangat kerja karyawan tetap bagian adinistrasi pada PTP Nusatara XIV (Persero) PKS Luwu, sehingga disarankan agar pimpinan perusahaan hendaknya mempertahankan kebijakan kompensasi tersebut.
\end{abstract}

Kata kunci : kompensasi,semangat kerja,karyawan 


\section{Pendahuluan}

\section{Latar Belakang}

Dalam menghadapi era globalisasi sumber daya manusia memegang peranan yang sangat dominan dalam kegiatan atau aktivitas atau kegiatan perusahaan. Berhasil tidaknya suatu perusahaan banyak bergantung pada kemampuan sumber daya manusia dalam melaksanakan pekerjaan yang diberikan.oleh karena itu,pimpinan perusahaan dituntut untuk memperlakukan karyawan dengan baik dan memandang mereka sebagai manusia yang mempunyai kebutuhan baik materi maupun non materi serta mengetahui,menyadari dan berusaha agar dapat memenuhi kebutuhan karyawannya, sehingga karyawan dapat bekerja sesuai dengan harapan perusahaan. Salah satu caranya adalah dengan memberikan kompensasi.

Dengan adanya pemberian kompensasi yang sesuai kepada karyawan merupakan hal yang sangat penting bagi perusahaan dan karyawan. Perusahaan akan mendapatkan karyawan yang bersedia bekerja dan menjalankan tugas-tugas dengan baik, sedangkan karyawan merasa pemberian kompensasi sebagai penghargaan atas kerja yang telah dilaksanan. Oleh karena itu, pimpinan harus menyadari pentingnya kompensasi dalam mendapatkan karyawan-karyawan yang kompeten dan menjaga agar karyawan yang telah ada merasa nyaman bekerja dala perusahaan dan tidk berkeinginan unutk meninggalkan perusahaan.

Semangat kerja merupakan hal yang sangat penting dalam setiap uasaha kerja sama sekelompok orang dalam suatu organisasi, semangat kerja yang tinggi akan menghasilkan produktivitas kerja yang tinggi dan mempermudah perusahaan dalam pencapain tujuan yang telah ditetapkan. Masalah Penelitian ini adalah adakah pengaruh antara kompensasi dengan semnagat kerja karyawan PTP Nusantara XIV (Presero) PKS Luwu unit I?. Tujuan dari penelitian ini yaitu : Untuk mengetahui tingkat pengaruh kompensasi dengan semangat kerja karyawan pada PTP Nusantara XIV (Persero) PKS Luwu Unit.

\section{Metode Penelitian}

Tempat dan Waktu Penelitian

Penelitian ini dilakukan di PTP Nusantara XIV (Persero) PKS Luwu Unit I yang berada di Burau.

Jenis dan Sumber Data

1. Data Primer

2. Data Sekunder

Populasi dan Sampel

Populasi yang dijadikan objek dalam penelitian ini adalah seluruh karyawan tetap bukan staff yang bekerja dibagian administrasi PTP Nusantara XIV (Persero) 
Unit usaha burau Luwu Utara, sedangkan sampel yang diambil minimal 30 sampel, yang ditarik dengan menggunakan rumus Slovin yang selajutnya dibagikan kuesioner dengan metode purvosive sampling.

\section{Metode Pengumpulan Data}

Metode pengumpulan data yang digunakan adalah : (a) Observisi; Yaitu metode pengumpulan data dengan cara mengadakan kunjungan dan pengamatan langsung di PTP Nusantara XIV (Persero) PKS Luwu Unit I, (b) Wawancara; Yaitu metode pengumpulan data yag dilakukan tanya jawab tentang hal-hal yang kurang jelas terkait dengan kegiatan penelitian, (c) Kuesioner; Yaitu metode pengumpulan data dengan cara mengajukan pertanyaan tertutup secara tertulis dan dijawab dengan jawaban yang tersedia oleh responden, (d) Dokumen; Yaitu metode yang digunakan untuk mengetahui gejala peristiwa yang etrjadi dalam lokasi penelitian.

Metode Analisis Data

Metode analisis data yang digunakan dalam penelitian ini adalah sebagai berikut :

Analisis korelasi Rank Spearman

$$
\mathrm{rs}=1 \frac{6 \sum_{t-1}^{n} d i^{2}}{\mathrm{~N}^{2}-\mathrm{N}}
$$

Keterangan

$\mathrm{rs}=$ koefisien korelasi antar variabel

$\mathrm{di}=$ perbedaan urutan (rank) pasangan variabel

$\mathrm{N}=$ jumlah responden

\section{Uji t}

Adapun taraf sigfikansi yang ditentukan adalah sebesar 0,5 atau taraf kepercayaan 95\%, sehigga apabila ternyata nilai hitung lebih besar dari pada nilai pada harga tabel (angka kritis), maka Ha diterima, sebaliknya jika nilai hitung lebih kecil dari harga tabet maka Ho diterima dan Ha ditolak.

Rumus yang digunakan :

$$
\mathrm{T}_{\text {test }}=\mathrm{r}_{\mathrm{s}} \sqrt{\frac{N-2}{1-\left(r_{2}\right)^{2}}}
$$




\section{Hasil Penelitian Dan Pembahasan}

Tabel 36 rekapitulasi data responden mengenai variabel kompensasi terhadap semangat kerja karyawan

\begin{tabular}{|c|c|c|c|c|c|c|}
\hline Nomor & & & & rangking & selisih ranking & $d^{2}$ \\
\hline & $X$ & $\mathrm{Y}$ & $X$ & $\mathrm{Y}$ & (d) & \\
\hline 1. & 41 & 63 & 20 & 21,5 & $-1,5$ & 2,25 \\
\hline 2. & 40 & 52 & 12,5 & 5,5 & 7 & 49 \\
\hline 3. & 40 & 52 & 12,5 & 5,5 & 7 & 49 \\
\hline 4. & 40 & 57 & 12,5 & 1,5 & 1 & 1 \\
\hline 5. & 40 & 61 & 12,5 & 15,5 & -3 & 9 \\
\hline 6. & 40 & 61 & 12,5 & 15,5 & -3 & 9 \\
\hline 7. & 40 & 52 & 12,5 & 5,5 & 7 & 49 \\
\hline 8. & 38 & 53 & 4 & 10 & -6 & 36 \\
\hline 9. & 40 & 52 & 12,5 & 5,5 & 7 & 49 \\
\hline 10. & 40 & 63 & 12,5 & 21,5 & -9 & 81 \\
\hline 11. & 42 & 58 & 22 & 13 & 9 & 81 \\
\hline 12. & 40 & 52 & 12,5 & 5,5 & 7 & 49 \\
\hline 13. & 40 & 52 & 12,5 & 5,5 & 7 & 49 \\
\hline 14. & 40 & 57 & 12,5 & 11,5 & 1 & 1 \\
\hline 15. & 33 & 48 & 2 & 1 & 1 & 1 \\
\hline 16. & 40 & $\begin{array}{l}59 \\
2,25\end{array}$ & 12,5 & 14 & $-1,5$ & \\
\hline 17. & 40 & 52 & 12,5 & 5,5 & 7 & 49 \\
\hline 18. & 40 & $\begin{array}{l}64 \\
182,5\end{array}$ & 12,5 & 26 & $-13,5$ & \\
\hline 19. & 29 & $\begin{array}{l}62 \\
272,5\end{array}$ & 1 & 17,5 & $-16,5$ & \\
\hline 20. & 42 & 64 & 22 & 26 & -4 & 16 \\
\hline 21. & 44 & 62 & 26,5 & 17,5 & 9 & 81 \\
\hline 22. & 43 & 63 & 24,5 & 21,5 & 3 & 9 \\
\hline 23. & 50 & 65 & 29 & 29 & 0 & 0 \\
\hline 24. & 43 & $\begin{array}{l}64 \\
2,25\end{array}$ & 24,5 & 26 & $-1,5$ & \\
\hline 25. & 38 & $\begin{array}{l}63 \\
306,25\end{array}$ & 4 & 21,5 & $-17,5$ & \\
\hline 26. & 50 & 65 & 29 & 29 & 0 & 0 \\
\hline 27. & 44 & 63 & 26,5 & 21,5 & 5 & 25 \\
\hline 28. & 50 & 65 & 29 & 29 & 0 & 0 \\
\hline 29. & 38 & $\begin{array}{l}62 \\
182,25\end{array}$ & 4 & 17,5 & $-13,5$ & \\
\hline 30. & 42 & $\begin{array}{l}63 \\
0,25 \\
\end{array}$ & 22 & 21,5 & 0,5 & \\
\hline & & 1643 & & & & \\
\hline
\end{tabular}

Sumber : data penelitian

Berdasarkan data di atas dapat diketahui : 


$$
\begin{aligned}
& N=30 \\
& \Sigma \mathrm{d}^{2}=1643
\end{aligned}
$$

Hasil perhitung menunjukkan bahwa nilai rs adalah 0,608. Kemudian nilai hitug dibandingkan dengan nilai tabel untuk $\mathrm{N}=30, \alpha=5 \%$ yaitu 0,364 . Dari data tersebut dapat dilihat bahwa nilai rs hitung lebih besar dari nilai rs tabel (rs hitung $>$ ), yag berarti hipotesis alternatif (Ha) diterima dan hipotesis statistik Ho ditolak. Jadi kesimpulannya adalah ada hubungan antara kompensasi dengan semangat kerja karyawan pada PTP Nusantara XIV (Persero) PKS Luwu. Berdasarka pedoman dari interprstasi Sugiono maka koefisiensi korelasi yang diperoleh sebesar 0,608 berada pada interval 0,600 - 0,799 yantergolong mempunyai pengaruh kuat.

\section{Pembahasan}

Berdasarkan hasil penelitian analisis dan teori yang telah dikemukakan sebelumnya, maka dapat dikatakan bahwa kompensasi (variabel X) dan semangat kerja karyawan (variabel Y) dirangking, kemudian dihitung selisi rangking (di) dari kedua variabel tersebut. Selisi rangking dikuadratkan $\left(\mathrm{di}^{2}\right)$ dan diperoleh hasil sebesar 1643. Langkah selanjutnya yaitu menghitung $\Sigma$ Tx dan $\Sigma$ Ty untuk memutuskan $\Sigma \mathrm{x}^{2}$ dan $\Sigma \mathrm{y}^{2}$. Hasil perhitungan menunjukkan $\Sigma \mathrm{Tx}=234,5$ dan $\Sigma$ ty $=$ 65. Perhitungan tersebut digunakan untuk menentukan besarnya rs.

Hasil perhitungan kolerasi rank soearma dengan taraf signifikansi 5\% didapatkan hasil sebesar 0,608 maka dapat disimpulkan bahwa ada pengaruh antara kompensasi terhadap semangat kerja karyawan tetap bagian administrasi pada PTP Nusantara XIV (Persero) PKS Luwu. Hasil uji signifikan diperoleh nilai tanggapan hitung sebesar 4,09 sedangkan nilai t tabel untuk $\mathrm{df}=\mathrm{N}-2=28$ dengan tingkat signifikan 5\%. Berdasarkan data tersebut dapat diketahui bahwa terdapat pengaruh yang kuat antara kompensasi dengan semangat kerja karyawan tetap bagian administrasi pada PTP Nusantara XIV (Persero) PKS Luwu Burau.

\section{Penutup}

Kesimpulan penelitian ini adalah bahwa kompensasi berpengaruh terhadap semangat kerja karyawan tetap bagian adinistrasi pada PTP Nusatara XIV (Persero) PKS Luwu. Adapun saran dari penelitian ini adalah: (a) Pimpinan hendaknya mempertahankan kebijakan kompensasi tersebut agar semangat kerja karyawan tetap tinggi, sehingga tujuan kedua belah phak, baik perusahaan maupun karyawan dapat tercapai dengan baik, (b) Untuk mahasiswa dan para penelti lainnya, agar kiranya dapat melanjutkan pencarian terhadap fakto-faktor lain yang juga memberi pengaruh terhadap semangat kerja karyawan di perusahaan yang ada di kota palopo 


\section{Daftar Pustaka}

Anoraga, Pndji dan Suyati. 1995. Psikologi Industi dan Sosial. Jakarta: PT. Dunia Pustaka Jaya

Burham Bungin. 2007. Penelitian kuantitatif-komunikasi, Ekinomi dan Kebijakan Publik serta Ilmu Sosial lainnya. Edisi Satu. Jakarta. Prenada Media Grup.

Dessler, Gray. 1997. Manajemen Personalia. Jakarta: Erlangga.

Gitosudarmo, I dan I Nyoman Sudita. 1995. Perilaku Keorganisasian. Yogyakarta: BPFE

Hadi, sutrisno. 1994. Metodologi Researceh. Yogyakarta: Andi Offset 1995. Metodolgi Research. Yogyakarta: Andi Offset.

Handoko, t. Hani. 1998. Manajemen Personalia dan Sumber Daya Manusia. Yogyakarta: BPFE

2001. MANAJEMEN Personalia dan Sumber Daya Manusia. Yogyakarta: BPFE

Hasibuan, S. P. MALAYU. 1999. Organisasi dan Motivasi. Jakarta: Bumi Aksara

2002. organisasi dan Motivasi. Jakarta: Bumi Aksara

Koentjoroningrat. 1991. Metode-metode Penelitian Masyarakat. Jakarta: PT. Gramedia Pustaka Utama

Mangkunegara. Anwar Prabu. 2004. Manajemen Sumber Daya Manusia Perusahaan. Bandung: remaja Rosdakrya:

Manullang, M. 1994. Manajemen Personalia. Jakarta: Ghalia Indonesia

Moekijat. 1999. Manajemen Sumberdaya Manusia (Manajemen Kepegawaian). Bandung: Mandar Maju

Nawawi, Hadari, 1997. Manajemen Sumber Daya Manusia. Jakarta: Ghalia Indonesia

2001. manajemen Sumber Daya Manusia. Jakarta: Ghalia Indonesia

Nazir, M. 1999. Metode Penelitian. Jakarta: Indonesia

Nitisemito, Alex S. 1992. Manajemen Personalia Manajemen Sumber Daya Manusia). Jakarta: Ghalia Indonesia. 